\title{
Kemampuan Kebertahanan Masyarakat pada Permukiman Rawan Banjir di Kecamatan Barabai, Kabupaten Hulu Sungai Tengah
}

\author{
Madalia Indrasari ${ }^{1}$ \\ Badan Perencanaan Pembangunan, Penelitian dan Pengembangan Daerah \\ Kabupaten Hulu Sungai Tengah, Kalimantan Selatan, Indonesia
}

\section{Iwan Rudiarto}

Departemen Perencanaan Wilayah dan Kota, Universitas Diponegoro

Semarang, Indonesia

Artikel Masuk : 13 Desember 2019

Artikel Diterima : 9 Maret 2020

Tersedia Online : 31 Agustus 2020

\begin{abstract}
Abstrak: Banjir musiman yang terjadi pada kawasan permukiman berdampak pada kondisi sosial ekonomi masyarakat yang secara bertahap akan menimbulkan tingkatan dalam kebertahanan. Kebertahanan tersebut terjadi karena adanya dorongan masyarakat yang terpapar bencana banjir untuk menyerap dan mengatasi gangguan yang terjadi serta memulihkan diri untuk tetap melangsungkan kehidupan, termasuk pada masyarakat yang tinggal pada permukiman rawan banjir di Kecamatan Barabai. Penelitian ini bertujuan untuk menganalisis kemampuan kebertahanan masyarakat pada kawasan permukiman rawan banjir di Kecamatan Barabai. Metode yang digunakan dalam penelitian ini adalah deskriptif kuantitatif dengan metode scoring yang penilaiannya berdasarkan Resilience Radar Indeks (RRI). Penelitian ini mencakup penilaian dimensi sosial, ekonomi, kesiapsiagaan dan fisik. Hasil dari penelitian menemukan bahwa unsur yang berketahanan tinggi adalah dimensi sosial, dan yang berketahanan rendah adalah dimensi fisik. Secara agregat masyarakat pada permukiman rawan banjir di Kecamatan Barabai memiliki kemampuan kebertahanan pada tingkat sedang dalam menghadapi bencana banjir.
\end{abstract}

Kata Kunci: bencana banjir; kebertahanan; permukiman rawan banjir

Abstract: Seasonal floods that occur in residential areas affect the socio-economic conditions of the community which will gradually lead to a level of survival. Resilience occurs because of the encouragement of the community that exposed to flood disasters to absorb and overcome the disturbances and get recover to keep continue the life, including to the community who live in flood-prone settlements in Barabai District. This study aims to analyze the ability of community survival as resilience in flood-prone areas in Barabai District. The method used in this research is quantitative descriptive with scoring method whose assessment is based on the Resilience Radar index. This research asseses the social, economic, preparedness and

\footnotetext{
${ }^{1}$ Korespondensi Penulis: Badan Perencanaan Pembangunan, Penelitian dan Pengembangan Daerah Kabupaten Hulu Sungai Tengah, Kalimantan Selatan, Indonesia Email: madaliaindrasari26@gmail.com
} 


\section{Kemampuan Kebertahanan Masyarakat pada Permukiman Rawan Banjir. . .}

physical dimensions. The results of the study found that the high-resilience element of the community resilience in Barabai is social dimension, and the low-resilience element is physical dimension. In aggregate, the community in flood-prone settlements in Barabai has a medium level of survival capability to flood disaster.

Keywords: flood disasters; flood-prone settlements; resilience

\section{Pendahuluan}

Bencana banjir merupakan salah satu bencana yang sering terjadi di dunia (Seejata et al., 2018). Bencana banjir memiliki banyak faktor penyebab, baik curah hujan yang tinggi, gelombang pasang, dataran yang sangat rendah, deforestasi daerah hulu, penyempitan Daerah Aliran Sungai (DAS) maupun alih fungsi lahan yang tidak tepat (Svetlana et al., 2015). Menurut Lee \& Brody (2018), banjir tidak semata merupakan bencana yang disebabkan oleh kondisi hidrometeorologi saja, namun juga ada peran serta aktivitas manusia yang menyebabkan banjir dapat terjadi, seperti penggunaan lahan yang tidak terarah dan tidak berdasarkan kesesuaian lahannya. Bourenane, Bouhadad, \& Guettouche (2019) menambahkan salah satu penyebab banjir yang sering terjadi adalah pertumbuhan penduduk yang tidak terkendali sehingga menyebabkan meningkatnya urbanisasi permukiman yang tak terarah, termasuk bermukim pada kawasan rawan banjir. Salah satu contohnya pada Maxaquene A, salah satu permukiman pada kawasan perkotaan di Maputo, Mozambique yang berada pada kawasan rawan banjir. Banjir pada kawasan tersebut menjadi berdampak besar karena kawasan permukiman tersebut minim fasilitas pendukung untuk mengurangi banjir serta kurang mendapat perhatian dari pihak terkait (Zehra et al., 2019). Permukiman pada kawasan rawan banjir lainnya juga terdapat pada Kota Constantine di. Kota Algeria terletak pada dataran rendah di wilayah pertemuan dua sungai, yaitu Sungai Boumerzoug dan Sungai Rhumel, sehingga dalam kota ini terdapat permukiman rawan bencana banjir (Bourenane et al., 2019).

Permasalahan banjir, terutama banjir pada kawasan permukiman memang menjadi tantangan yang serius bagi para pemangku kepentingan, termasuk bagi Pemerintah Kabupaten Hulu Sungai Tengah. Hal ini dikarenakan, selain berpengaruh terhadap terganggunya aktivitas kawasan perkotaan (Scherzer, Lujala, \& Rød, 2019), banjir juga berdampak terhadap kehidupan masyarakat pada kawasan permukiman rawan banjir dan aktivitasnya (Feofilovs \& Romagnoli, 2017). Banjir memang merupakan bagian dari proses alam, akan tetapi jika banjir tersebut sudah melewati batas daratan, maka sudah bisa dipastikan banjir akan membawa kerugian dan dapat mengancam bahaya (Bertilsson et al., 2019). Adanya gangguan aktivitas tersebut mengindikasikan dampak banjir yang dialami oleh masyarakat (Qasim et al., 2016). Dampak dan kerugian ini terjadi akibat kerentanan masyarakat yang tinggi saat menghadapi bencana banjir yang terjadi (Mohanty, Hussain, Mishra, Kattel, \& Pal, 2019). Besarnya tantangan permasalahan banjir ini juga terjadi di Kecamatan Barabai, yang merupakan pusat kegiatan sekaligus sebagai ibukota dari Kabupaten Hulu Sungai Tengah. Kecamatan Barabai merupakan kecamatan dengan luasan terkecil dibandingkan dengan kecamatan-kecamatan lain yang ada di Kabupaten Hulu Sungai Tengah, namun memiliki jumlah penduduk paling banyak dengan kondisi kawasan permukiman yang cukup padat. Kondisi banjir yang sering terjadi pada kawasan permukiman di beberapa kelurahan/desa di Kecamatan Barabai menjadikan pentingnya penelitian ini dilakukan khususnya untuk menganalisis kemampuan kebertahanan masyarakat yang tinggal pada permukiman yang rawan banjir di Kecamatan Barabai selama ini. 
Penelitian tentang kebertahanan masyarakat terhadap banjir sudah banyak dilakukan. Namun penelitian tentang kebertahanan masyarakat pada permukiman rawan banjir khususnya di wilayah Kecamatan Barabai belum pernah dilakukan. Selama ini penelitian mengenai banjir yang dilakukan di Kecamatan Barabai lebih banyak kepada studi pengendalian banjir dan penanggulangan banjir (Prabowo, 2018), pemetaan risiko banjir (Kumalawati \& Angriani, 2017; Kumalawati, Angriani, \& Murliawan, 2016), dan tinjauan bantaran Sungai Barabai (Hayati, Agoes, \& Julianoor, 2014), dan belum ada penelitian yang mengukur kemampuan kebertahanan masyarakat yang tinggal pada permukiman rawan banjir di Kecamatan Barabai. Penelitian ini secara spesifik berfokus pada kebaruan lokasi, dengan tema/topik yang sejenis, namun berbeda lokasi, dengan kondisi fisik kawasan dan budaya masyarakat yang berbeda sehingga dapat memberikan kontribusi pengetahuan lain. Berdasarkan latar belakang tersebut, maka menjadi penting untuk menganalisis seberapa besar kemampuan kebertahanan masyarakat yang tinggal pada permukiman rawan banjir di Kecamatan Barabai, karena selama ini masyarakat pada kawasan tersebut yang paling mengalami dampak dan kerugian yang diakibatkan oleh banjir. Sebagaimana dalam Rahmawati \& Rudiarto (2019) dijelaskan bahwa untuk mengurangi kerugian akibat bencana maka masyarakat terdampak bencana harus memiliki ketahanan. Semakin besar kemampuan masyarakat dalam bertahan, semakin siap masyarakat tersebut menuju adaptasi bencana (Frazier, Thompson, Dezzani, \& Butsick, 2013). Oleh karena itu mengukur ketahanan masyarakat pada suatu wilayah dalam menghadapi bencana sangat penting, karena hasilnya akan berkontribusi terhadap bagaimana strategi dan kebijakan mitigasi yang tepat terhadap wilayah tersebut (Moghadas, Asadzadeh, Vafeidis, Fekete, \& Kötter, 2019), sehingga dapat menentukan arahan adaptasi dan mitigasi bencana berbasis masyarakat yang sesuai dengan karakteristik kawasan tersebut serta sesuai dengan kondisi sosial masyarakat pada wilayah tersebut (Handayani, Surya, Anggraeni, \& Setyono, 2019). Oleh karena itu, penelitian ini bertujuan untuk menganalisis kemampuan kebertahanan masyarakat pada kawasan permukiman rawan banjir di Kecamatan Barabai.

\section{Metode Penelitian}

\section{Lokasi Penelitian}

Kecamatan Barabai merupakan kecamatan dengan luas lahan terkecil di Kabupaten Hulu Sungai Tengah, Provinsi Kalimantan Selatan yang memiliki hanya $4.074 \mathrm{Ha}$ atau 2,30\% dari keseluruhan luas Kabupaten Hulu Sungai Tengah yang memiliki luas 177.077 Ha. Meskipun merupakan kecamatan terkecil, namun sebagaimana ditentukan dalam Rencana Tata Ruang Wilayah (RTRW) Kabupaten Hulu Sungai Tengah yang ditetapkan dalam peraturan daerah, Kecamatan Barabai merupakan kawasan pusat perkotaan dan pusat aktivitas kabupaten, baik aktivitas ekonomi, aktivitas pemerintahan dan perkantoran hingga aktivitas pendidikan. Pada kawasan tengah perkotaan Barabai terdapat bentangan Sungai Barabai. Panjang keseluruhan sungai dari hulu ke hilir sekitar 40,73 km, dengan bagian hulu berada di Gunung Periok, Panitiranggang Hulu dan Tilai, melewati kawasan perkotaan Barabai dan bagian hilir mengalir ke arah Sungai Nagara (Prabowo, 2018). Pada sepanjang bentangan Sungai Barabai inilah sebagian besar permukiman berada.

Pada sepanjang sungai di kawasan perkotaan Barabai terdapat permukiman padat pada sisi kanan kiri sungai, sedangkan dijelaskan dalam UNESCO (2007) bahwa salah satu penyebab besarnya dampak banjir adalah terbangunnya permukiman pada dataran banjir dan sekitar sungai. Setiap musim hujan menjelang akhir tahun curah hujan di Kecamatan Barabai meningkat, Sungai Barabai meluap dan naik ke daratan hingga ke kawasan permukiman di sekitarnya meliputi enam kelurahan dan dua desa, yaitu Kelurahan Barabai Timur, Kelurahan Barabai Selatan, Kelurahan Barabai Barat, Kelurahan Barabai Utara, 
Kelurahan Barabai Darat, Kelurahan Bukat, Desa Mandingin dan Desa Pajukungan. Hal ini menyebabkan kawasan permukiman di sekitar sungai tersebut menjadi rawan tergenang banjir setiap musim hujan. Kawasan rawan banjir merupakan kawasan atau wilayah yang memiliki potensi besar mengalami bencana banjir berdasarkan faktor-faktor yang memengaruhinya (Samela, Albano, Sole, \& Manfreda, 2018). Permukiman yang tergenang banjir tidak hanya pada kawasan permukiman yang tepat berada di pinggir Sungai Barabai. Pada beberapa titik kawasan, permukiman yang memiliki jarak 300 meter dari sungai juga mengalami banjir dikarenakan kondisi lahan yang sangat rendah dan menjadi larian air hujan. Gambaran sebaran kawasan terbangun permukiman rawan tergenang banjir pada lokasi penelitian dapat dilihat pada Gambar 1.

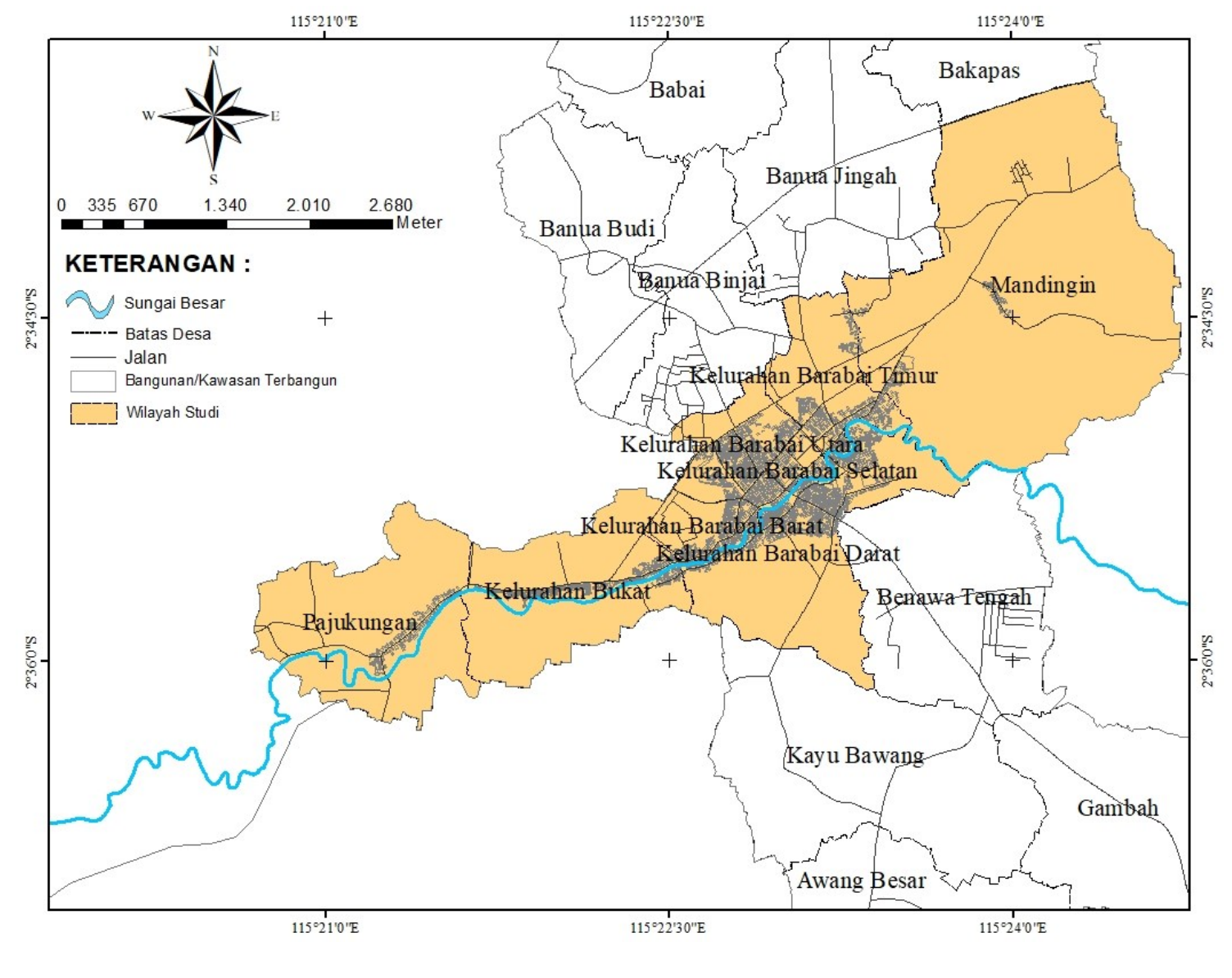

Gambar 1. Peta Sebaran Kawasan Terbangun Permukiman Rawan Banjir

Permukiman pada kawasan sekitar Sungai Barabai sudah ada sejak lama. Jumlah penduduk pada kawasan tersebut pun semakin meningkat setiap tahun. Hal ini karena Kecamatan Barabai merupakan pusat perkotaan dari Kabupaten Hulu Sungai Tengah sehingga menjadi pusat aktivitas dan sangat memungkinkan mengakibatkan terjadinya perpindahan penduduk dari luar menuju Kecamatan Barabai. Dengan meningkatnya jumlah penduduk, maka kebutuhan akan lahan menjadi meningkat, khususnya lahan permukiman. Namun kondisi keterbatasan lahan dan kondisi ekonomi, memungkinkan untuk menjadi alasan meluasnya kawasan permukiman di sepanjang Sungai Barabai.

Permukiman yang padat pada sekitar Sungai Barabai terlihat dengan aktivitas di sungai yang dilakukan masyarakat yang menempati permukiman tersebut. Rumah tinggal 
pada permukiman tersebut dibangun sangat dekat dengan tepi sungai, bahkan beberapa di antaranya dibangun di atas badan sungai, begitu juga dengan fasilitas umum yang ada pada permukiman. Sungai Barabai memiliki peranan besar dalam kehidupan masyarakat yang bermukim di sekitarnya, karena Sungai Barabai selama ini menopang kebutuhan air bagi sebagian besar masyarakat yang bermukim di sekitarnya, dan selain itu juga sebagai drainase alami bagi pengairan pada Kecamatan Barabai. Pada Sungai Barabai juga sering terdapat aktivitas mandi, cuci dan pembuangan pada jamban. Pada pinggiran Sungai Barabai hanya sebagian yang diperkuat dengan batu kali maupun pemasangan bronjong pada tebing sungai, Gambaran visual kondisi Sungai Barabai beserta lingkungan permukiman di dekatnya dapat dilihat pada Gambar 2.
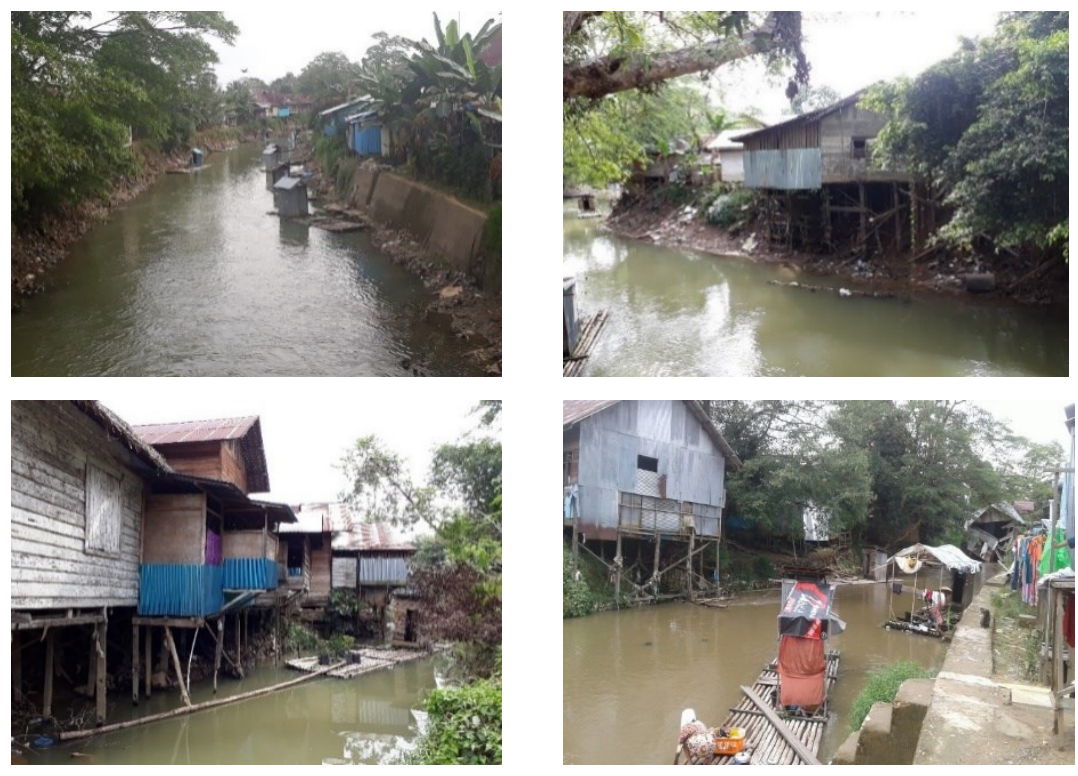

Gambar 2. Kondisi Bagian Sungai Barabai dan Permukiman di Sekitarnya

\section{Metode Analisis}

Dalam penelitian mengenai ketahanan masyarakat terhadap banjir, terdapat banyak penelitian senada dan menggunakan aspek yang sama, yang membedakan adalah indikator dan metodenya, atau dapat juga menggunakan indikator yang sama, dengan aspek yang berbeda. Penelitian Scherzer et al. (2019) menghitung ketahanan masyarakat dengan menggunakan variabel sosial, ekonomi, institusi, modal komunitas, ketahanan infrastruktur dan perumahan serta lingkungan dengan menggunakan metode Baseline Resilience Indicators of Communities (BRIC). Penelitian kebertahanan dengan metode lain juga dilakukan oleh Ciptaningrum \& Pamungkas (2017) dengan menggunakan metode Climate and Disaster Resilience Initiative (CDRI).

Penelitian ini menggunakan variabel-variabel terpilih yang telah diidentifikasi indikator-indikatornya. Variabel pertama adalah dimensi sosial dengan indikator pendidikan, usia, lama tinggal, keterlibatan dengan aktivitas sosial, dan asuransi kesehatan. Dimensi sosial dipilih sebagai variabel karena aspek sosial dianggap merupakan aspek penting dalam mengidentifikasi kemampuan kebertahanan masyarakat terhadap bencana, karena unsur sosial melekat dengan masyarakat baik individu maupun komunitas dan masyarakat juga yang pertama kali merasakan dampak dari adanya bencana (Imperiale \& Vanclay, 2016). Variabel kedua adalah dimensi ekonomi dengan indikator pekerjaan, 
pendapatan, jumlah anggota keluarga dalam satu rumah yang bekerja, tabungan yang dimiliki dan pengaruh bencana banjir terhadap ekonomi rumah tangga. Dimensi ekonomi dipilih sebagai variabel karena unsur ekonomi juga dinilai memiliki pengaruh besar dalam mengukur kemampuan masyarakat dalam bertahan terhadap bencana. Ketahanan ekonomi berkaitan dengan layaknya pendapatan atau pemasukan dalam suatu rumah tangga (Qasim et al., 2016). Variabel ketiga adalah dimensi kesiapsiagaan, dengan indikator pemahamaman akan bencana banjir, bantuan dari pemerintah, kewaspadaan sebelum terjadi banjir, dampak banjir, dan pemulihan pasca bencana banjir. Dimensi kesiapsiagaan dipilih sebagai salah satu aspek untuk mengukur ketahanan masyarakat terhadap bencana karena masyarakat atau rumah tangga yang memiliki kesiapsiagaan yang baik akan mampu mengurangi risiko bencana, meminimalisasi banyaknya kerugian serta membantu percepatan masa pemulihan setelah terjadi bencana (Bolte et al., 2017). Variabel terakhir yang digunakan untuk mengukur kemampuan kebertahanan masyarakat terhadap banjir adalah dimensi fisik yang menggunakan indikator lokasi, material bangunan, fasilitas dan aksesibilitas. Dimensi fisik dipilih sebagai variabel karena unsur fisik merupakan salah satu faktor penunjang kehidupan masyarakat dalam beraktivitas (Rosyid \& Rudiarto, 2014). Variabel dan indikator dalam penelitian ini merupakan modifikasi dari Qasim et al. (2016) dan Rudiarto, Handayani, Wijaya, \& Insani (2019) karena menggunakan aspek-aspek dasar yang berpengaruh untuk mengukur kemampuan kebertahanan masyarakat pada Kecamatan Barabai dan telah disesuaikan dengan keadaan di lokasi studi. Variabel dan indikator yang digunakan dalam penelitian ini lebih jelas dapat dilihat pada Tabel 1.

Tabel 1. Variabel dan Indikator yang Digunakan

\begin{tabular}{llll}
\hline \multicolumn{1}{c}{ Dimensi Sosial } & \multicolumn{1}{c}{ Dimensi Ekonomi } & Dimensi Kesiapsiagaan & Dimensi Fisik \\
\hline - pendidikan & - pekerjaan & - pemahaman akan bencana & - lokasi \\
- usia & - pendapatan & banjir & - material \\
- aktivitas sosial & - jumlah anggota keluarga & - bantuan pemerintah & bangunan \\
- lama tinggal & dalam 1 rumah yang bekerja & - kewaspadaan sebelum & - fasilitas \\
- asuransi & - tabungan & terjadi banjir & - aksesibilitas \\
- kesehatan & - pengaruh bencana banjir & - dampak banjir & \\
& terhadap ekonomi rumah & - pemulihan pasca bencana & \\
& tangga & banjir & \\
\hline
\end{tabular}

Sampel penelitian dalam studi ini adalah rumah tangga pada permukiman rawan banjir di Kecamatan Barabai. Sampel dihitung dengan menggunakan rumus Slovin (Sugiyono, 2016), dan dari perhitungan tersebut didapatkan sampel penelitian sebanyak 100 rumah tangga dari 10.249 rumah tangga yang tersebar pada kawasan permukiman rawan banjir di Kecamatan Barabai yang selama ini selalu tergenang banjir yaitu pada Kelurahan Barabai Timur, Kelurahan Barabai Selatan, Kelurahan Barabai Barat, Kelurahan Barabai Utara, Kelurahan Barabai Darat, Kelurahan Bukat, Desa Mandingin dan Desa Pajukungan. Pengumpulan sampel penelitian dilakukan dengan menggunakan metode sampel secara acak pada permukiman yang tergenang banjir. Data penelitian diperoleh dari observasi lapangan dan penyebaran kuesioner terhadap sampel penelitian. Data yang didapatkan tersebut dianalisis dengan menggunakan metode scoring dengan penilaian berdasarkan Resilience Index yang diadopsi dari Bolte et al. (2017). Metode scoring ini dipilih karena lebih memudahkan dalam menetapkan data-data menjadi nilai kualitatif yang kemudian dapat diukur tingkat kemampuan kebertahanan masyarakatnya melalui radar ketahanan (Resilience Radar).

Analisis dalam penelitian ini dilakukan secara bertahap per indikator, per aspek hingga menghitung resilience index secara agregat. Penilaian dalam analisis ini menggunakan indeks Resilience Radar dengan ketentuan score index diberikan dalam 
rentang nilai antara $0,00-1,00$. Nilai 0,00 diberikan terhadap nilai ketahanan yang paling rendah dan nilai 1,00 diberikan terhadap nilai ketahanan yang paling tinggi (Bolte et al., 2017). Hasil rata-rata dari skor seluruh aspek kemudian diinterpretasikan ke dalam tingkat ketahanan dengan rentang kebertahanan sangat tinggi, tinggi, sedang, rendah dan sangat rendah. Penelitian Rudiarto et al. (2019) juga menggunakan metode yang sama, namun dalam penelitian tersebut lebih mengarah kepada menentukan livelihood resilience dengan menggunakan dimensi sosial, ekonomi, lingkungan dan fisik-infrastruktur. Skor indeks dan interpretasi ketahanan berdasar Resilience Radar dapat dilihat pada Tabel 2.

Tabel 2. Resilience Radar Index

\begin{tabular}{cc}
\hline Skor Indeks & Interpretasi Ketahanan \\
\hline $0,81-1,00$ & Sangat tinggi \\
$0,61-0,80$ & Tinggi \\
$0,41-0,60$ & Sedang \\
$0,21-0,40$ & Rendah \\
$0,00-0,20$ & Sangat rendah \\
\hline
\end{tabular}

Sumber: Bolte et al. 2017

\section{Hasil dan Pembahasan}

\section{Dimensi Sosial}

Hasil analisis menunjukkan bahwa masyarakat pada permukiman rawan banjir di Kecamatan Barabai memiliki kemampuan kebertahanan sosial yang tinggi. Indikator yang paling berpengaruh adalah keikutsertaan masyarakatnya dalam asuransi kesehatan. Hal ini dikarenakan banyak responden yang sudah menyadari pentingnya proteksi kesehatan, juga karena bantuan dari pemerintah yang mewajibkan masyarakatnya yang kurang mampu untuk diberikan bantuan keikutsertaan Badan Penyelenggara Jaminan Sosial (BPJS) dengan gratis iuran. Pada indikator lain ditemukan bahwa sebagian besar responden sudah lama tinggal di kawasan tinggalnya, yaitu lebih dari lima belas tahun. Hal ini mengindikasikan ketahanan masyarakat untuk tinggal pada kawasan tersebut walaupun selalu mengalami banjir setiap tahun. Hal tersebut kemudian berkaitan dengan aktivitas sosialnya. Berdasarkan pengamatan terhadap responden, diketahui bahwa hampir setiap rumah tangga mengikuti kegiatan sosial. Selain itu, pada kawasan tempat tinggal tersebut juga masyarakatnya saling guyup dan gotong royong apabila ada warganya yang memiliki hajatan atau mendapat musibah. Hal ini mengindikasikan besarnya ikatan kekeluargaan antarwarga dalam lingkungan tempat tinggal mereka. Berdasarkan tingkat pendidikan diketahui bahwa sebagian besar kepala keluarga responden setidaknya menamatkan pendidikan setara Sekolah Menengah Atas (SMA), sehingga dianggap memiliki tingkat pengetahuan dan tingkat nalar yang cukup baik untuk dapat melakukan adaptasi terhadap banjir. Sedangkan pada indikator usia, masuk dalam interpretasi sedang karena sebagian besar usia kepala keluarga responden berada dalam rentang usia 40-64 tahun dan beberapa sudah berusia di atas 64 tahun.

Indikator dimensi sosial dalam penelitian ini berbeda dengan penelitian oleh Rahmayana \& Handayani (2019), yang dalam penelitiannya mengukur ketahanan masyarakat. Perbedaannya adalah dalam penelitian tersebut variabel sosial yang dianalisis hanya menggunakan indikator hubungan dalam keluarga dan indikator interaksi/hubungan sosial, sehingga hanya melihat hubungan antara individu dengan keluarga dan komunitas saja. Diagram resilience radar dimensi sosial ini dapat dilihat pada Gambar 3. 


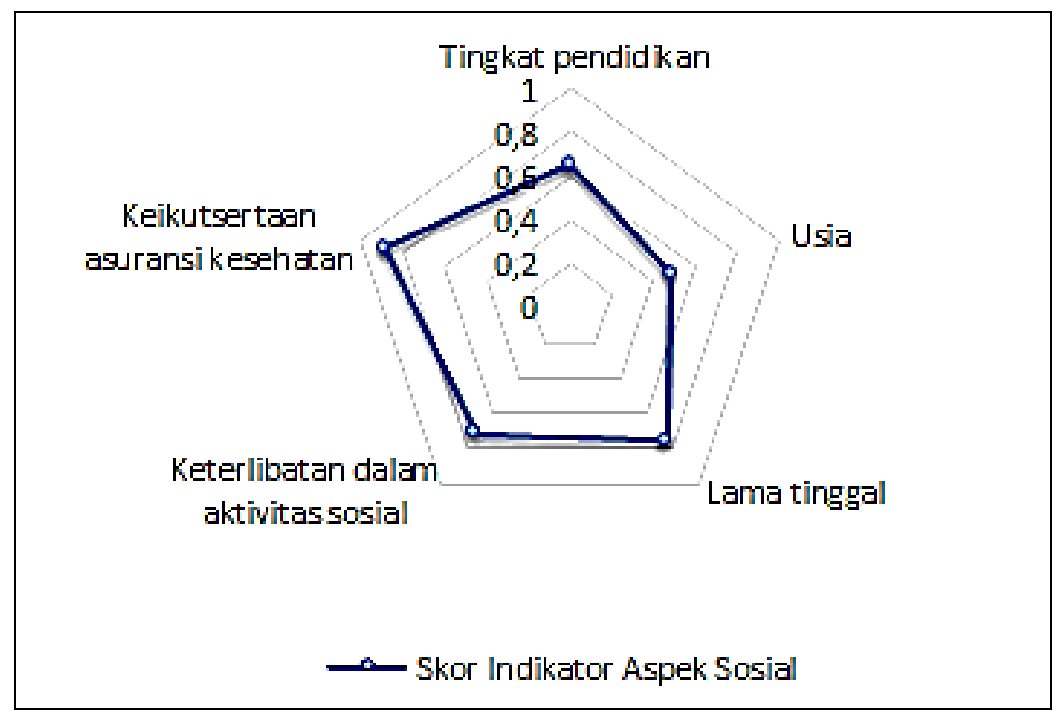

Gambar 3. Resilience Radar Dimensi Sosial Permukiman Rawan Banjir Kecamatan Barabai

\section{Dimensi Ekonomi}

Pada dimensi ekonomi, indikator yang paling berpengaruh adalah pekerjaan. Sebagian besar masyarakat memiliki mata pencaharian sebagai wiraswasta/dagang, dan sebagai PNS/polisi/tentara/swasta tetap, selebihnya adalah bertani/buruh, pegawai tidak tetap/honorer dan tidak bekerja. Pendapatan menunjukkan tingkat kemampuan rendah, dikarenakan sebagian besar rumah tangga memiliki besaran pendapatan yang kecil atau kurang dari Upah Minimum Kabupaten/Kota (UMK/UMP). Hal ini berpengaruh pada ketahanan aspek ekonomi terkait pemenuhan kebutuhan hidup masyarakat dan kebutuhan darurat di saat terjadi bencana banjir. Pada indikator tabungan, masih banyak responden yang belum mempersiapkan dana cadangan berupa tabungan, yang dipengaruhi dari kecilnya pendapatan per bulan yang diterima sehingga tidak dapat menyisihkan dana untuk tabungan. Selain itu, sebagian besar rumah tangga hanya mengandalkan satu orang yang bekerja, yaitu kepala keluarga. Terjadinya bencana banjir juga berpengaruh terhadap perekonomian keluarga karena sebagian besar memiliki mata pencaharian berdagang, bertani/buruh dan dalam kondisi banjir maka aktivitas ekonomi tersebut tidak dapat mereka lakukan dan akhirnya mengurangi pendapatan. Hasil analisis menunjukkan kebertahanan ekonomi masyarakat berada pada tingkat interpretasi sedang.

Pada dimensi ini terdapat beberapa indikator yang sama dalam Rudiarto et al. (2019), yaitu pendapatan, tabungan, dan dampak bencana terhadap kondisi keuangan dengan justifikasi bahwa pendapatan dan tabungan dapat mengindikasikan pemasukan yang dimiliki dalam rumah tangga, dan dampak bencana terhadap kondisi keuangan digunakan untuk melihat seberapa besar dampak bencana tersebut mampu membuat masyarakat tetap mampu bertahan dalam bencana. Hasil analisis juga menunjukkan bahwa tabungan dan dampak bencana menunjukkan kebertahanan yang sama pada tingkat sedang. Hanya saja dalam penelitian di Kecamatan Barabai, indikator pendapatan memiliki nilai yang sangat kecil. Hal ini dikarenakan sebagian besar pendapatan responden kurang dari 2 juta. Diagram resilience radar dimensi ekonomi ini dapat dilihat pada Gambar 4. 


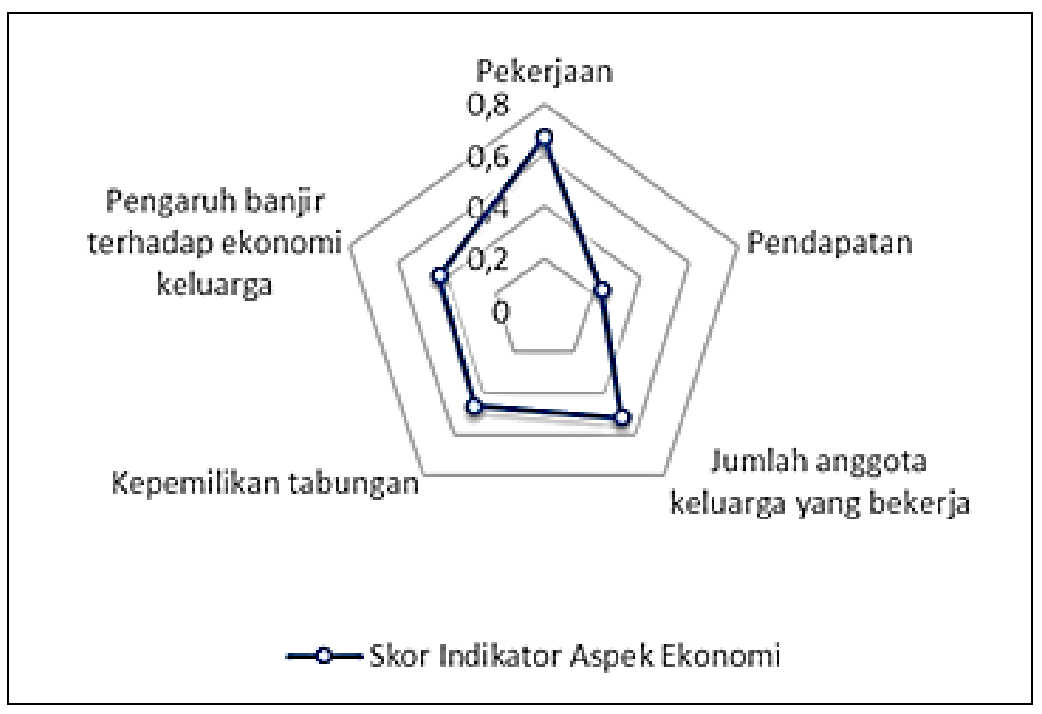

\section{Gambar 4. Resilience Radar Dimensi Ekonomi Permukiman Rawan Banjir Kecamatan Barabai}

\section{Dimensi Kesiapsiagaan}

Berdasarkan hasil analisis didapatkan bahwa kemampuan kesiapsiagaan masyarakat pada permukiman rawan banjir di Kecamatan Barabai termasuk sedang. Dalam Qasim et al. (2016) terdapat indikator yang senada, namun dalam penamaan variabel institusi. Variabel tersebut menunjukkan tingkat kebertahanan rendah dengan hampir semua indikator memiliki skor rendah. Sebenarnya dalam kasus ketahanan kesiapsiagaan pada permukiman rawan banjir Kecamatan Barabai ini juga sebagian besar indikatornya menunjukkan kebertahanan yang rendah, yaitu bantuan dari pemerintah, kewaspadaan sebelum terjadi banjir, dan dampak bencana banjir. Untuk pemahaman bencana banjir menunjukkan kebertahanan sedang. Namun karena pada indikator pemulihan pasca bencana memiliki skor sangat tinggi, maka jika dinilai rata-rata keseluruhan aspek kesiapsiagaan menjadi memiliki kebertahanan sedang. Meskipun pemulihan pasca bencana banjir memiliki interpretasi sangat tinggi, namun yang dimaksud dalam penelitian ini adalah kemampuan masyarakat pada permukiman tersebut untuk membersihkan tempat tinggalnya pasca banjir, dan kemampuan untuk kembali beraktivitas dan bekerja. Kondisi masyarakat yang sebagian besar sudah memahami bahaya bencana banjir serta kemampuan untuk pulih dari bencana yang cukup tinggi ini seharusnya dapat menjadi modal yang cukup baik bagi masyarakat untuk memiliki kesiapsiagaan yang tinggi dalam menghadapi banjir. Namun, dilihat dari indikator kemampuan keberketahanan masyarakat dalam menghadapi dampak bencana banjir yang masih rendah, menunjukkan bahwa kemampuan masyarakatnya untuk bertahan dalam mengalami dampak bencana banjir masih perlu ditingkatkan menjadi lebih baik lagi.

Dalam hal kesiapsiagaan, penelitian ini sekaligus menguatkan penelitian Razikin, Kumalawati, \& Arisanty (2017) yang meneliti penanggulangan bencana bencana banjir di Kecamatan Barabai berdasarkan persepsi masyarakatnya, bahwa masih kurangnya sosialisasi dan pelatihan dari pemerintah kepada masyarakat sebagai bagian dari kesiapan kewaspadaan sebelum bencana banjir. Keseluruhan indikator kesiapsiagaan tergambarkan dalam diagram resilience radar pada Gambar 5. 


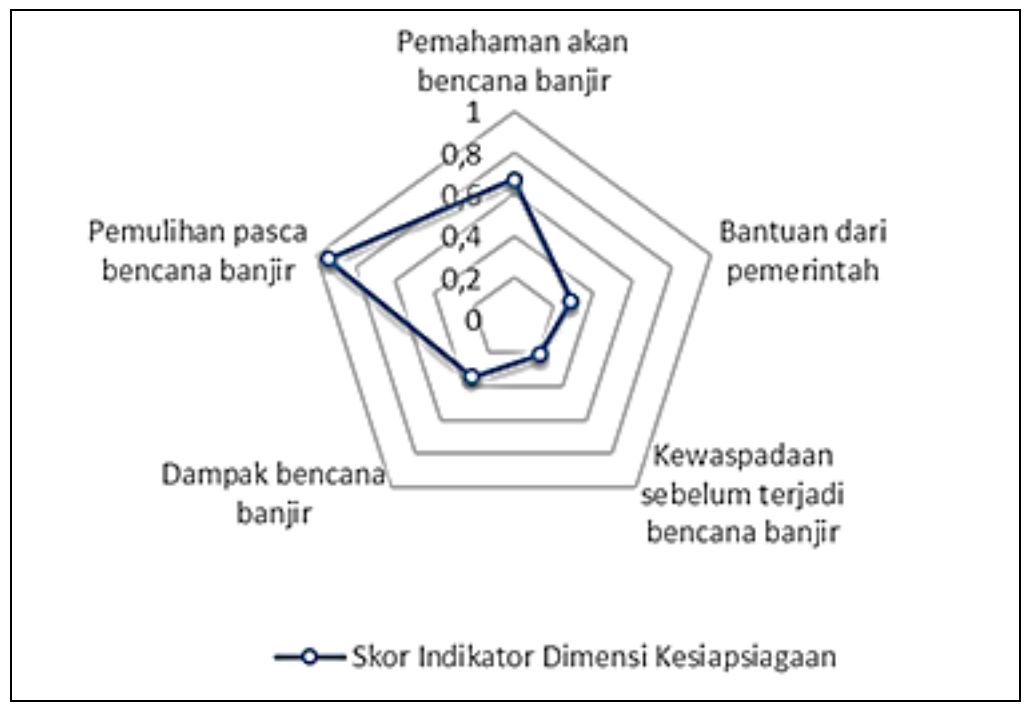

Gambar 5. Resilience Radar Dimensi Kesiapsiagaan Permukiman Rawan Banjir Kecamatan Barabai

\section{Dimensi Fisik}

Kemampuan fisik masyarakat permukiman pada kawasan rawan banjir di Kecamatan Barabai termasuk rendah. Dari empat indikator, tiga di antaranya menunjukkan interpretasi rendah dan sangat rendah. Kondisi bahan bangunan rumah yang ditempati oleh rumah tangga sebagian besar terbangun dari bahan kayu atau papan. Bahan bangunan tersebut cenderung mudah mengalami kerusakan apalagi jika sering mengalami banjir. Selain itu lokasi permukiman penduduk yang jaraknya dekat dengan sungai juga menyebabkan kawasan tersebut rentan mengalami banjir, terutama pada rumah tangga yang sangat dekat jaraknya dengan sungai dapat mengalami banjir hingga lebih dari satu kali dalam setahun. Hal ini disebabkan apabila terjadi luapan sungai yang luas ke daratan, kawasan permukiman yang berada di sisi sungai adalah kawasan pertama yang terdampak genangan banjir. Kondisi ini tidak senada dengan Peraturan Pemerintah RI Nomor 38 tahun 2011 tentang sungai, yang menetapkan ketentuan mengenai jarak antara sungai dengan bangunan yang harus dipenuhi sebagai syarat untuk bermukim di kawasan sekitar sungai.

Sebagian besar kawasan permukiman daerah penelitian masih banyak yang belum memiliki saluran pembuangan air/selokan. Pada beberapa kawasan yang memiliki saluran pembuangan air, ternyata banyak yang tidak berfungsi dengan baik sehingga air genangan tidak mengalir. Kondisi masyarakat pada kawasan permukiman yang cukup padat dan berada dekat dengan sungai menjadi semakin rendah kemampuan kebertahanannya karena tidak diimbangi dengan pemenuhan fasilitas umum yang seharusnya dapat berfungsi sebagai penunjang kawasan permukiman.

Indikator yang berpengaruh terhadap tingginya nilai kebertahanan fisik ini adalah kemudahan aksesibilitas bagi masyarakat Kecamatan Barabai. Hal ini disebabkan oleh kecilnya luasan lahan Kecamatan Barabai sehingga jarak antar tempat tidak begitu jauh. Selain itu pada kawasan permukiman sampel penelitian merupakan kawasan tengah perkotaan Barabai sehingga dekat dengan fasilitas pendidikan, fasilitas kesehatan, fasilitas perdagangan/jasa dan lokasi kerja. Diagram resilience radar dimensi fisik dapat dilihat pada Gambar 6. 


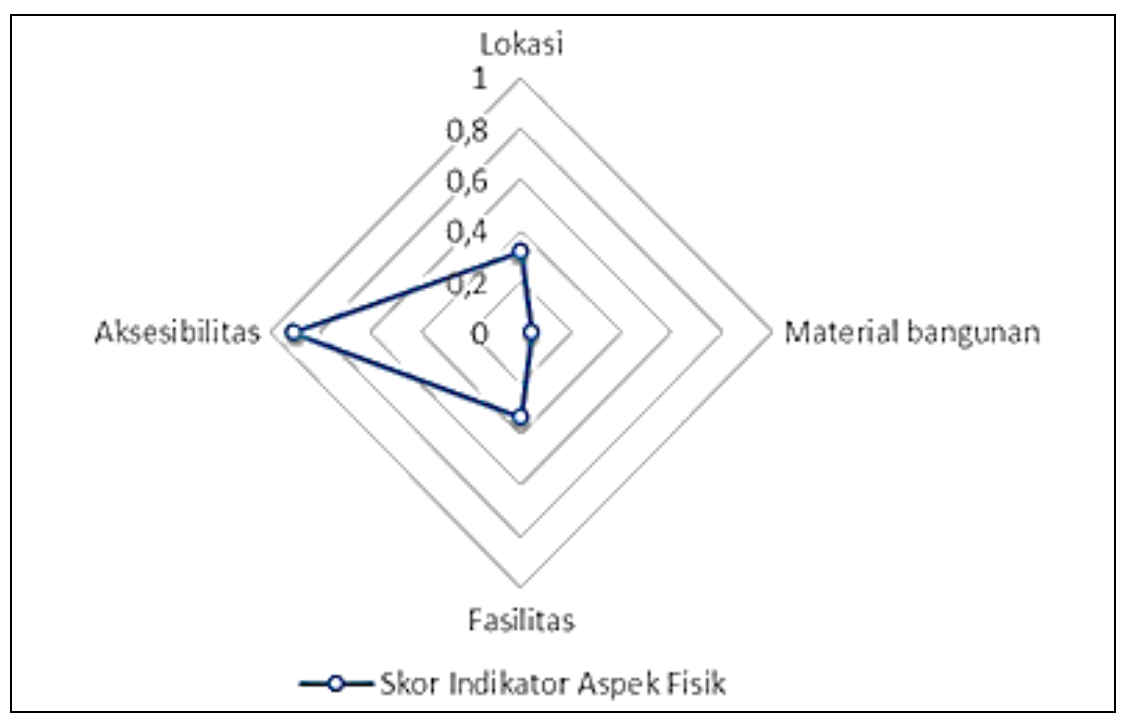

\section{Gambar 6. Resilience Radar Dimensi Fisik Permukiman Rawan Banjir Kecamatan Barabai}

\section{Kemampuan Kebertahanan Masyarakat Permukiman Rawan Banjir}

Berdasarkan hasil analisis per dimensi, didapatkan interpretasi kemampuan kebertahanan masing-masing aspek. Dimensi sosial menunjukkan kemampuan kebertahanan tinggi, dimensi ekonomi dan kesiapsiagaan menunjukkan kemampuan kebertahanan sedang, dan dimensi sosial menunjukkan kemampuan kebertahanan rendah. Hasil analisis per dimensi ini kemudian diakumulasi dan dilakukan perhitungan nilai ratarata untuk mendapatkan nilai secara agregat. Hasil yang diukur berdasarkan Resilience Index dari Bolte et al. (2017) menunjukkan bahwa kemampuan kebertahanan masyarakat yang tinggal pada permukiman rawan banjir di Kecamatan Barabai adalah pada kategori sedang. Dari hasil ini, maka dapat dikatakan bahwa permukiman rawan banjir Kecamatan Barabai masih perlu peningkatan ketahanan lagi, karena kedepannya banjir masih dapat terus terjadi setiap tahun sehingga masyarakatnya harus bergerak dan berubah ke arah yang lebih baik lagi. Utami, Soemarno, Surjono, \& Bisri (2014) menjelaskan bahwa pada permukiman dekat sungai memerlukan analisis risiko bencana yang mempertimbangkan hingga sepuluh tahun ke depan, dan memiliki adaptasi penanganan bencana yang berbeda tergantung tingkat risikonya dan didukung dengan pengetahuan kebertahanan masyarakat pada permukimannya.

Penelitian ini memiliki sudut pandang yang berbeda dalam menganalisis kebertahanan dengan Kusumastuti, Viverita, Husodo, Suardi, \& Damarsari (2014) dan Rahmawati \& Rudiarto (2019). Kedua penelitian tersebut menganalisis dan mengembangkan kebertahanan dengan menganalisis terlebih dahulu kerentanan dan kesiapsiagaannya, masing-masing memiliki dimensi dan subdimensi tersendiri yang merupakan pengembangan dari unsur sosial, kapasitas masyarakat, ekonomi, institusional, infrastruktur dan bahaya. Sedangkan penelitian ini menganalisis empat dimensi sosial, ekonomi, kesiapsiagaan dan fisik untuk menemukan kebertahanan masing-masing dimensi dan secara agregat. Analisis ini memiliki manfaat untuk mengidentifikasi kemampuan kebertahanan per dimensi dan kemudian menilainya secara keseluruhan, sehingga upaya untuk meningkatkan kebertahanan dan mengatasi kerentanan dapat disesuaikan dengan kondisi pada masing-masing dimensi. Diagram resilience radar kemampuan kebertahanan masyarakat permukiman rawan banjir di Kecamatan Barabai dapat dilihat pada Gambar 7. 


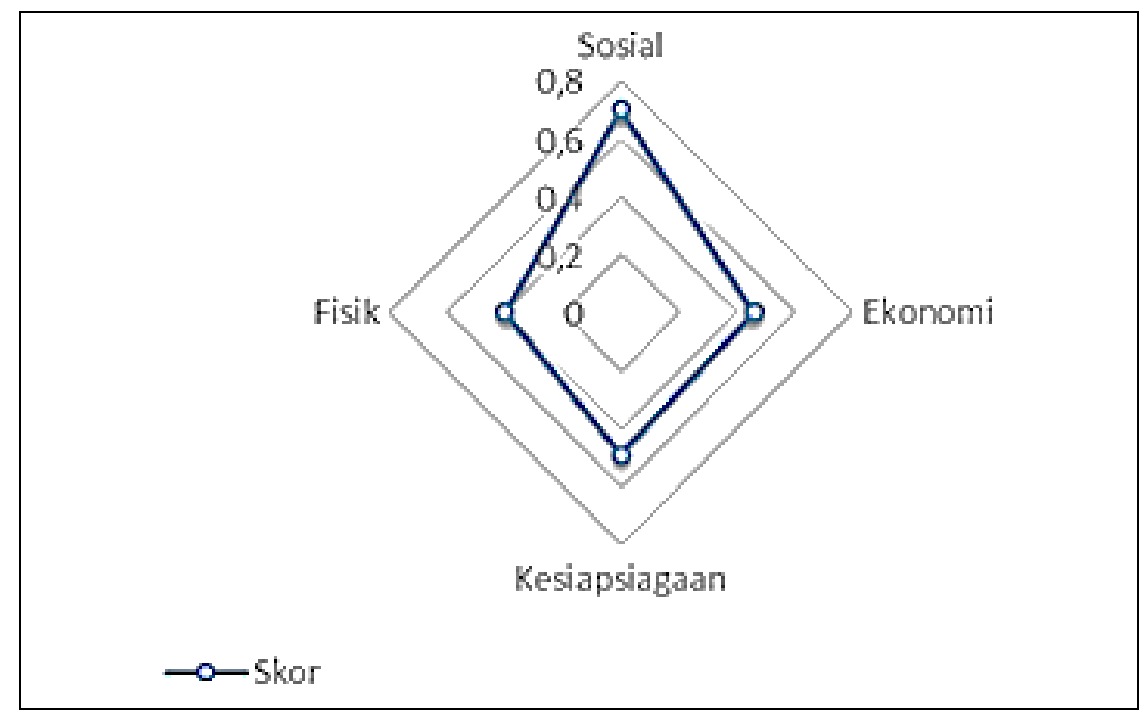

\section{Gambar 7. Resilience Radar Kemampuan Kebertahanan Masyarakat Permukiman Rawan Banjir Kecamatan Barabai}

\section{Kesimpulan}

Kemampuan kebertahanan masyarakat yang tinggal pada permukiman rawan banjir di Kecamatan Barabai berada pada tingkat sedang. Kondisi ini menunjukkan bahwa pada dasarnya masyarakat pada kawasan permukiman tersebut sebenarnya memiliki keinginan untuk bertahan, terlihat dari $83 \%$ responden sampel penelitian menyatakan tidak ingin pindah dari tempat tinggal saat ini walaupun sering mengalami dampak dari banjir mengalami kerugian akibat banjir. Dalam konteks pengembangan wilayah, suatu wilayah harus direncanakan dan dibangun dengan prinsip pembangunan berkelanjutan, dan salah satunya adalah mengarah pada wilayah atau kota yang berketahanan terhadap bencana. Dalam membangun wilayah yang berketahanan maka masyarakat di dalamnya harus memiliki kemampuan bertahan dalam menghadapi bencana. Sebagaimana dalam penelitian ini masyarakatnya memiliki keinginan yang tinggi untuk tetap dapat tinggal pada kawasan permukiman rawan banjir, namun keinginan untuk bertahan ini tentunya harus diimbangi dengan kemampuan untuk bertahan, baik dari kemampuan sosial, kemampuan ekonomi, kemampuan kesiapsiagaan maupun kemampuan dari aspek fisik, mengingat penduduk pada kawasan rawan banjir ini cukup padat dan terkonsentrasi pada kawasan sepanjang sungai. Seiring dengan padatnya penduduk maka manajemen lingkungan pada kawasan tersebut harus semakin diperhatikan, seperti kebutuhan pengaliran air hasil buangan secara baik, pembuangan sampah maupun limbah agar tidak menjadi salah satu penyebab semakin parahnya banjir pada kawasan tersebut.

Hasil dari penelitian ini dapat menjadi masukan kontribusi pengetahuan dalam upaya meningkatkan kapasitas masyarakat Kecamatan Barabai dalam menghadapi banjir yang sering terjadi. Selain itu, penelitian ini juga dapat memperkaya bidang keilmuan penataan ruang, mengingat sebagaimana pernah ditetapkan dalam Hyogo Framework for Action (UNISDR, 2005), perencanaan tata ruang merupakan salah satu sarana untuk mengurangi risiko bencana, termasuk bencana banjir. Salah satu upaya pengurangan risiko bencana tersebut dapat dilakukan dengan membangun kapasitas dan kemampuan kebertahanan masyarakat yang mengalami dampak bencana tersebut (Carter et al., 2015), dan indeks 
kebertahanan terhadap bencana dapat digunakan untuk memonitoring upaya pengurangan risiko bencana (BNPB, 2018).

\section{Ucapan Terima Kasih}

Artikel ini merupakan bagian dari penelitian tentang ketahanan masyarakat terhadap banjir di Kecamatan Barabai yang dibiayai oleh Pusbindiklatren Bappenas. Penulis mengucapkan terima kasih kepada Pemerintah Kabupaten Hulu Sungai Tengah atas izin yang diberikan.

\section{Daftar Pustaka}

Bertilsson, L., Wiklund, K., Tebaldi, I. de M., Rezende, O. M., Verol, A. P., \& Miguez, M. G. (2019). Urban flood resilience - a multi-criteria index to integrate flood resilience into urban planning. Journal of Hydrology, 573(June), 970-982. doi:10.1016/j.jhydrol.2018.06.052.

BNPB. (2018). Indeks ketahanan daerah untuk monitoring indeks risiko bencana. Retrieved from https://bnpb.go.id/berita/indeks-ketahanan-daerah-untuk-monitoring-indeks-risiko-bencana.

Bolte, P., Orlowsky, D. B., Marr, S., Moore, S., Rahmadana, M. F., \& Sitompul, D. (2017). Resilience radar user manual. $\quad$ Retrieved from https://www.preparecenter.org/sites/default/files/resilience_radar_manual_v_1.1.pdf.

Bourenane, H., Bouhadad, Y., \& Guettouche, M. S. (2019). Flood hazard mapping in urban area using the hydrogeomorphological approach: case study of the Boumerzoug and Rhumel alluvial plains (Constantine city, NE Algeria). Journal of African Earth Sciences, 160(December), 103602. doi: 10.1016/j.jafrearsci.2019.103602.

Carter, J. G., Cavan, G., Connelly, A., Guy, S., Handley, J., \& Kazmierczak, A. (2015). Climate change and the city: Building capacity for urban adaptation. Progress in Planning, 95, 1-66. doi:10.1016/j.progress.2013.08.001.

Ciptaningrum, M. U., \& Pamungkas, A. (2017). Penilaian resiliensi dimensi sosial berdasarkan konsep Climate and Disaster Resilience Initiative ( CDRI ). Jurnal Teknik ITS, 6(2), 2-6.

Feofilovs, M., \& Romagnoli, F. (2017). Measuring community disaster resilience in the Latvian context: an apply case using a composite indicator approach. Energy Procedia, 113, 43-50. doi:10.1016/j.egypro.2017.04.012.

Frazier, T. G., Thompson, C. M., Dezzani, R. J., \& Butsick, D. (2013). Spatial and temporal quantification of resilience at the community scale. Applied Geography, 42, 95-107. doi:10.1016/j.apgeog.2013.05.004.

Handayani, W., Surya, P. I. H., Anggraeni, M., \& Setyono, J. S. (2019). Community-based disaster management : Assessing Local Preparedness Groups ( LPGs ) to build a resilient community in Semarang City , Indonesia. Disaster Advances, 12(5), 1-14.

Hayati, F., Agoes, H. F., \& Julianoor, N. E. (2014). Tinjauan bantaran banjir actual terhadap pp no. 38 tahun 2011 dan peraturan menteri PU no. 63 tahun 1993 di Sungai Barabai Kabupaten Hulu Sungai Tengah. Jurnal Poros Teknik, 6(2), 55-102.

Imperiale, A. J., \& Vanclay, F. (2016). Experiencing local community resilience in action: Learning from postdisaster communities. Journal of Rural Studies, 47, 204-219. doi:10.1016/j.jrurstud.2016.08.002.

Kumalawati, R., \& Angriani, F. (2017). Pemetaan risiko bencana banjir di Kabupaten Hulu Sungai Tengah. In Prosiding Seminar Nasional Geografi UMS 2017 Pengelolaan Sumberdaya Wilayah Berkelanjutan (pp. 118). Fakultas Geografi, Universitas Muhammadiyah Surakarta.

Kumalawati, R., Angriani, F., \& Murliawan, K. H. (2016). Pemetaan risiko banjir untuk evaluasi pengembangan permukiman di Kabupaten Hulu Sungai Tengah Kalimantan Selatan. In Seminar Nasional Peran Geospasial dalam Membingkai NKRI (pp. 157-164). Badan Informasi Geospasial.

Kusumastuti, R. D., Viverita, V., Husodo, Z. A., Suardi, L., \& Damarsari, D. N. (2014). Developing a resilience index towards natural disasters in Indonesia. International Journal of Disaster Risk Reduction, 10, 327340. doi:10.1016/j.ijdrr.2014.10.007. 
Lee, Y., \& Brody, S. D. (2018). Examining the impact of land use on flood losses in Seoul , Korea. Land Use Policy, 70(February 2017), 500-509. doi:10.1016/j.landusepol.2017.11.019.

Moghadas, M., Asadzadeh, A., Vafeidis, A., Fekete, A., \& Kötter, T. (2019). A multi-criteria approach for assessing urban flood resilience in Tehran, Iran. International Journal of Disaster Risk Reduction, 35, 101069. doi:10.1016/j.ijdrr.2019.101069.

Mohanty, A., Hussain, M., Mishra, M., Kattel, D. B., \& Pal, I. (2019). Exploring community resilience and early warning solution for flash floods, debris flow and landslides in conflict prone villages of Badakhshan, Afghanistan. International Journal of Disaster Risk Reduction, 33(July 2018), 5-15. doi:10.1016/j.ijdrr.2018.07.012.

Prabowo, E. (2018). Studi pengendalian banjir di Kota Barabai terkait rencana pembangunan bendungan Pancur Hanau Sungai Barabai Kabupaten Hulu Sungai Tengah. Jurnal Teknologi Berkelanjutan, 71), 43-51. doi:10.20527/jtb.v7i01.114.

Qasim, S., Qasim, M., Shrestha, R. P., Khan, A. N., Tun, K., \& Ashraf, M. (2016). Community resilience to flood hazards in Khyber Pukhthunkhwa province of Pakistan. International Journal of Disaster Risk Reduction, 18, 100-106. doi:10.1016/j.ijdrr.2016.03.009.

Rahmawati, I., \& Rudiarto, I. (2019). Framework considerations for rural resilience toward land degradation. In UNNES International Conference on Research Innovation and Commercialization 2018, KnE Social Sciences (pp. 266-275). doi:10.18502/kss.v3i18.4720.

Rahmayana, L., \& Handayani, W. (2019). Indeks ketahanan masyarakat pesisir Kecamatan Kampung Laut dalam menghadapi penyusutan Laguna Segara Anakan. Jurnal Pembangunan Wilayah dan Kota, 15(2), 96-107. doi:10.14710/pwk.v15i2.22157.

Razikin, P., Kumalawati, R., \& Arisanty, D. (2017). Strategi penanggulangan bencana banjir berdasarkan persepsi masyarakat di Kecamatan Barabai Kabupaten Hulu Sungai Tengah. Jurnal Pendidikan Geografi, 4(1), 27-39.

Rosyid, M., \& Rudiarto, I. (2014). Karakteristik sosial ekonomi masyarakat petani Kecamatan Bandar dalam sistem livelihood pedesaan. Geoplanning, 1(2), 74-84.

Rudiarto, I., Handayani, W., Wijaya, H. B., \& Insani, T. D. (2019). Rural livelihood resilience: An assessment of social, economic, environment, and physical dimensions. MATEC Web of Conferences, 280, 01002. doi:10.1051/matecconf/201928001002.

Samela, C., Albano, R., Sole, A., \& Manfreda, S. (2018). A GIS tool for cost-effective delineation of flood-prone areas. Computer, Environtment and Urban Systems, 79(July), 43-52. doi:10.1016/j.compenvurbsys.2018.01.013.

Scherzer, S., Lujala, P., \& Rød, J. K. (2019). A community resilience index for Norway: An adaptation of the Baseline Resilience Indicators for Communities (BRIC). International Journal of Disaster Risk Reduction, 36 (May), 101107. doi:10.1016/j.ijdrr.2019.101107.

Seejata, K., Yodying, A., Wongthadam, T., Mahavik, N., \& Tantanee, S. (2018). Assessment of flood hazard areas using analytical hierarchy process over the lower Yom Basin, Sukhothai Province. Procedia Engineering, 212, 340-347. doi:10.1016/j.proeng.2018.01.044.

Sugiyono. (2016). Metode penelitian kuantitatif, kualitatif dan R\&D. Bandung: PT. Alfabet.

Svetlana, D., Radovan, D., \& Ján, D. (2015). The economic impact of floods and their importance in different regions of the world with emphasis on Europe. Procedia Economics and Finance, 34(15), 649-655. doi:10.1016/S2212-5671(15)01681-0.

UNESCO. (2007). Petunjuk praktis partisipasi masyarakat dalam penanggulangan banjir. Jakarta: UNESCO Office.

UNISDR. (2005). Hyogo framework for action 2005-2015 : Building the resilience of nation and communities to disasters. Kobe, Hyogo, Japan.

Utami, S., Soemarno, S., Surjono, S., \& Bisri, M. (2014). Disaster risk and adaptation of settlement along the River Brantas in the context of sustainable development, Malang, Indonesia. Procedia Environmental Sciences, 20, 602-611. doi:10.1016/j.proenv.2014.03.073.

Zehra, D., Mbatha, S., Campos, L. C., Queface, A., Beleza, A., Cavoli, C., ... Parikh, P. (2019). Rapid flood risk assessment of informal urban settlements in Maputo , Mozambique: The case of Maxaquene A. International Journal of Disaster Risk Reduction, 4O(January), 101270. doi:10.1016/j.ijdrr.2019.101270. 